\title{
Analysis of Amino Acid Sequence of SARS-CoV, SARS-CoV-2, and MERS-CoV Spike Glycoproteins: Preliminary Study for Obtaining Universal Peptide Vaccine Candidates
}

\author{
Yani Suryani*, Opik Taupiqurrohman \\ Department of Biology, Faculty of Science and Technology, \\ Universitas Islam Negeri Sunan Gunung Djati Bandung \\ Jl. A.H. Nasution No. 105A, Bandung, West Java, Indonesia. 40614 \\ *Email: yani.suryani@uinsgd.ac.id
}

\begin{abstract}
In the manufacture of universal peptide vaccines, it is necessary to analyze the amino acids of the various candidates. Therefore, this study aims to examine the amino acids of the spike glycoproteins of SARS-CoV, SARS-CoV-2, and MERS CoV. The method used is the alignment of the amino acid spike glycoprotein between SARS-CoV with SARS-CoV-2, MERS CoV with SARS-CoV-2, and SARS-CoV with MERS-CoV using web-based software water emboss. The analysis result showed that SARS and SARS CoV-2 were very similar with $87 \%$ similarity and $76.4 \%$ identity values. In contrast, SARS CoV-2 with MERS and SARS with MERS were very different, having similarity and identity values less than $70 \%$. Therefore, it is reasonable to conclude that spike glycoprotein's peptide is only useful from attacks by the SARS-CoV and SARS-CoV-2 viruses.
\end{abstract}

Keywords: Coronavirus; COVID-19; MERS, peptide vaccine; SARS

Article History: Received 04 September 2020; Received in revised form 30 October 2020; Accepted 23 November 2020; Available online 30 December 2020

How to Cite This Article: Suryani Y, Taupiqurrohman O. 2020. Analysis of amino acid sequence of SARS-CoV, SARS-CoV-2, and MERS-CoV spike glycoproteins: preliminary study for obtaining universal peptide vaccine candidates. Biogenesis: Jurnal Ilmiah Biologi. vol 8(2): 185-194. doi: https://doi.org/10.24252/bio.v8i2.15696.

\section{INTRODUCTION}

Coronavirus is 65 to $125 \mathrm{~nm}$ in size and as a single-stranded RNA virus, it has the length of 26-32 kbp. Furthermore, it consists of four subfamilies of alpha $(\alpha)$, beta $(\beta)$, gamma $(\Upsilon)$, and delta $(\delta)$ (Shereen et al., 2020). Before now, the virus only infected animals, however, in the 2000s, there were known cases of SARS (Severe Acute Respiratory Syndrome), MERS (Middle East Respiratory Syndrome), and COVID-19 (Coronavirus Disease-2019) (Wang et al., 2013; Shereen et al., 2020). The Coronaviruses that cause SARS, MERS and COVID-19 are known as SARS-CoV (SARScoronavirus), MERS CoV (MERScoronavirus) and SARS CoV 2 (COVID-19) respectively.

SARS-CoV is an etiologic agent of acute respiratory syndrome (Liu et al., 2014), and was endemic in 2002-2003 (Peiris et al., 2003). MERS (Middle East Respiratory Syndrome) is an infectious disease caused by the MERS virus (MERS-CoV), and it has similar symptoms with SARS, that cause flu-like illnesses which is respiratory tract disruption (da Costa et al., 2020; Li et al., 2020). Both belong to the genus
Betacoronavirus (Schoeman \& Fielding, 2019; ICTV, 2020). Initially, MERS-CoV case was first identified in Saudi Arabia in September 2012 by camel-to-human transmission, and then by human-to-human transmission (Jeong et al., 2017) and spread to countries in the Middle East (Zumla et al., 2015), precisely in the Arabian Peninsula and its surroundings such as the United Arab Emirates, Qatar, Oman, Jordan, Kuwait, Yemen, Iran, Egypt, and Lebanon (Rampengan, 2016; Shapiro et al., 2016; WHO, 2016). Importations of MERS had been reported in France (Mailles et al., 2013; Puzelli et al., 2013), Italy (Puzelli et al., 2013), Spain (Rashid et al., 2013), United Kingdom (Thomas et al., 2014), Tunisia (Abroug et al., 2014), Malaysia (Cunha \& Opal, 2014), Philippines (Racelis et al., 2015), and Korea (Jeong et al., 2017) in the following years. The SARS-CoV-2 attack resurfaced at the end of 2019 in Wuhan, China, and has spread to almost all countries worldwide, and this condition was given the term COVID-19 (Corona Virus Disease-2019) (ICTV, 2020).

Vaccines for MERS, SARS and COVID-19 are yet to be discovered (Slamet et al., 2013) but 
the process continues to experience development. In addition, it consists of several amino acid residues (small proteins) (Subroto et $a l ., 2013$ ) and with the existence, it is possible to make a universal vaccine. This can serve a protective function against various types of antigens, which is primarily used for making peptide vaccines. Therefore, a strong similarity protein is needed to make a universal vaccine against coronaviruses (SARS, MERS and COVID-19) (Alouane et al., 2020; KhalajHedayati, 2020; Wu et al., 2020).

There have been many research related to the manufacture of vaccine candidates, one of which is the HPV (Human Papillomavirus). This study shows that the promising vaccine peptide candidate of the E1 protein obtained from HPV genome is LLITSNINA, from E5 is VLLCVCLLI and from E7 is LLMGTLGIV (Aprilyanto \& Sembiring, 2017). Furthermore, they have been tested in vitro, and the results are useful in activating the immune response.

One of the conditions for making a peptide vaccine is that the protein antigen should be located at the outer part of the virus in order to ease the purification process. The spike glycoprotein is used as a peptide vaccine candidate since its position is in the outer part, and it is possessed by all types of Coronavirus. Therefore, this protein is used as a candidate source for peptide vaccines for all kinds of Coronavirus.

Initially, the research was conducted to obtain an overview of its potential as a vaccine candidate. In addition, an explanation of their potential will be obtained by testing the similarity and identity for the amino acid sequence of spike glycoproteins.

\section{MATERIALS AND METHODS}

This research used the following materials; amino acid sequence of SARS-CoV-2, SARS$\mathrm{CoV}$ (SARS), and MERS-CoV (MERS) spike glycoprotein with NCBI having the Accession Number YP_009724390.1 (COVID-19), P59594, and A0A140AYZ5 respectively.

Work Procedures. This research was conducted in the following stages: SARS CoV2 (COVID-19) spike glycoprotein downloaded at https://www.ncbi.nlm.nih.gov/; SARS CoV spike glycoprotein downloaded at http://www.uniprot.org; MERS spike glycoprotein download at http://www.uniprot.org; alignment process between spike glycoproteins of COVID-19 with SARS in the https://www.ebi.ac.uk/Tools/psa/emboss_wate r/program; alignment between spike glycoproteins of COVID-19 with MERS in the https://www.ebi.ac.uk/Tools/psa/emboss_wate r/ program; alignment between spike glycoproteins of MERS with SARS in the program

https://www.ebi.ac.uk/Tools/psa/emboss_wate r/ program.

\section{RESULTS AND DISCUSSION Alignment result between COVID-19 with SARS.}

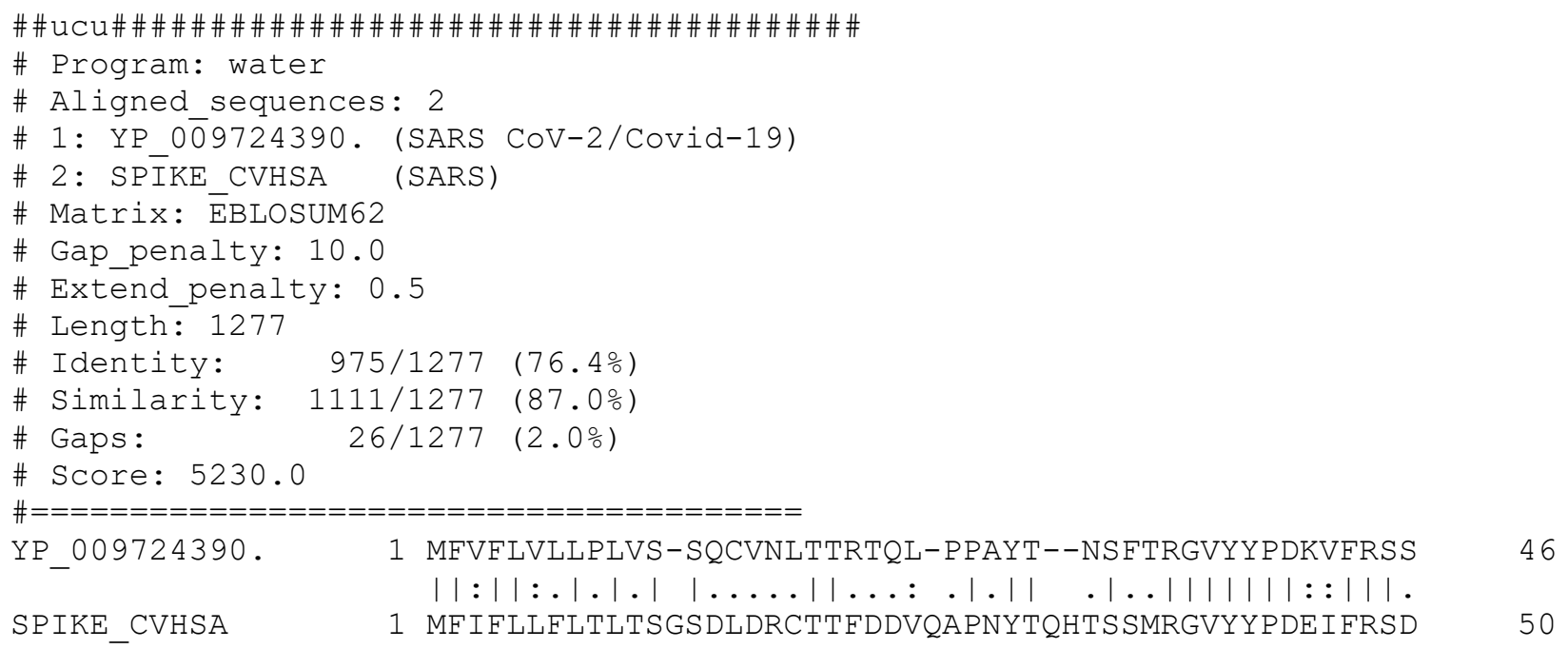




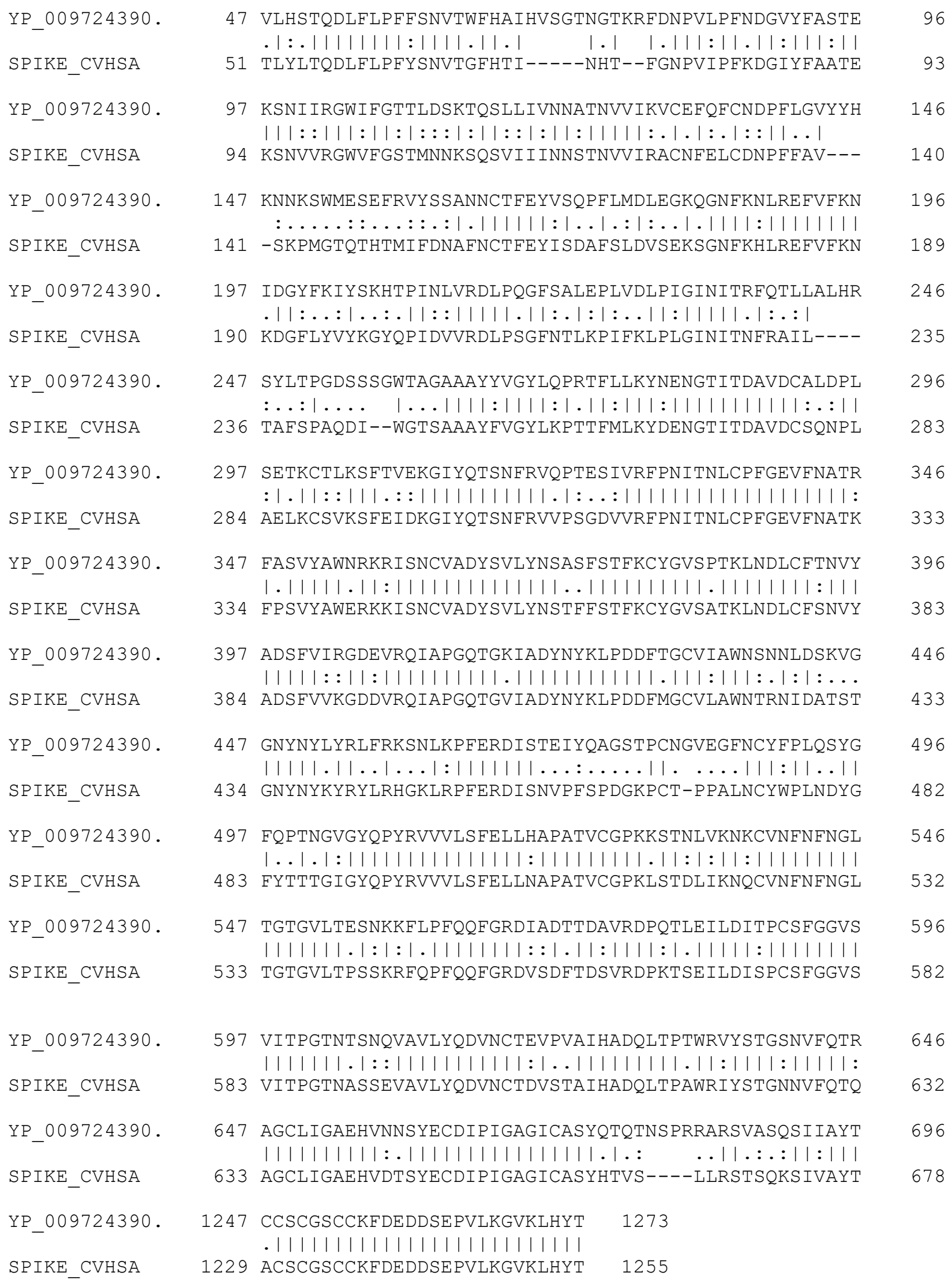

Fig. 1. Alignment result between SARS CoV-2 with SARS-CoV spike glycoproteins. 


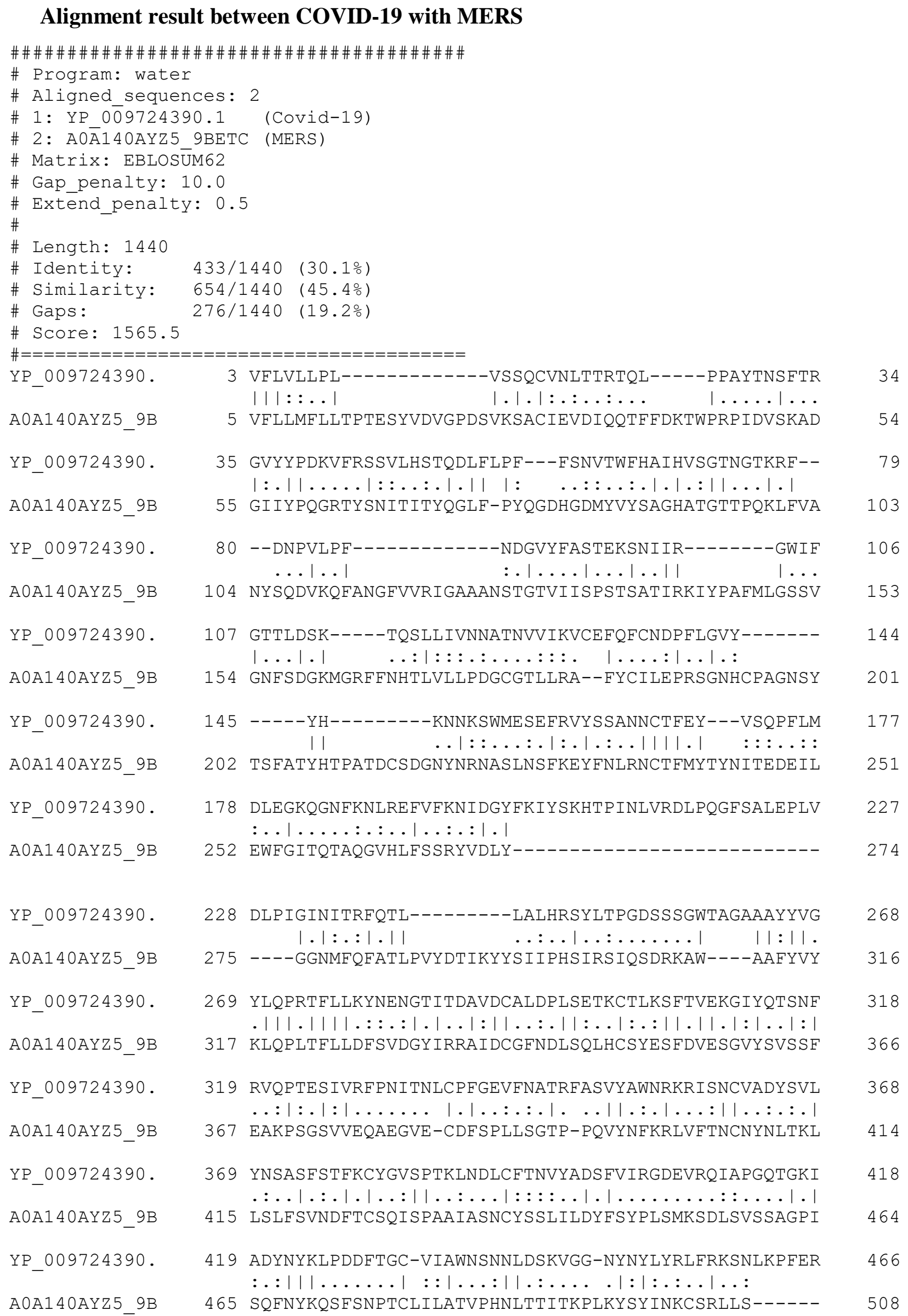




\begin{tabular}{|c|c|c|}
\hline YP_O09724390. & 467 & 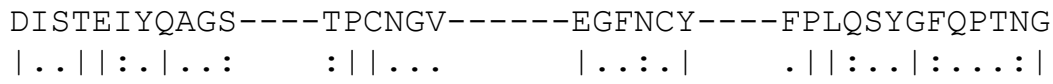 \\
\hline A0A140AYZ5_9B & 509 & DDRTEVPQLVNANQYSPCVSTVPSTVWEDGDYYRKQLSPLEGGGWLVASG \\
\hline YP_009724390. & 503 & VGYQPYRVVVLSFELLHAPAT----VCGPKKSTNLVK-----NKCVNFNF \\
\hline A0A140AYZ5_9B & 559 & $\begin{array}{c}\ldots \ldots . . \\
\text { STVAMTEQLQMGFGITVQYGTDTNSVCPKLEFANDTKIASQLGNCVEYSL }\end{array}$ \\
\hline YP_009724390. & 544 & 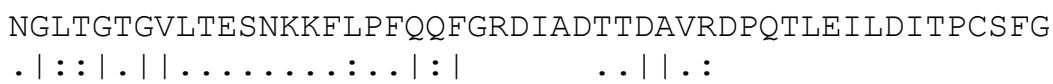 \\
\hline A0A140AYZ5_9B & 609 & YGVSGRGVFQNCTAVGVRQQRF------VYDAYQ---------------- \\
\hline YP_009724390. & 1175 & 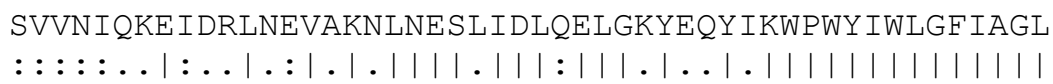 \\
\hline A0A140AYZ5_9B & 1258 & TLLDLTYEMLSLQQVVKALNESY I DLKELGNYTYYNKWPWY IWLGFIAGL \\
\hline YP_009724390. & 1225 & 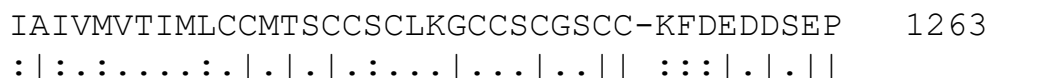 \\
\hline A0A140AYZ5_9B & 1308 & VALALCVFFILCCTGCGTNCMGKLKCNRCCDRYEEYDLEP \\
\hline
\end{tabular}

Fig. 2. Alignment Result between SARS CoV-2 with MERS CoV Spike Glycoproteins.

\section{Alignment result between SARS with MERS spike glycoproteins}

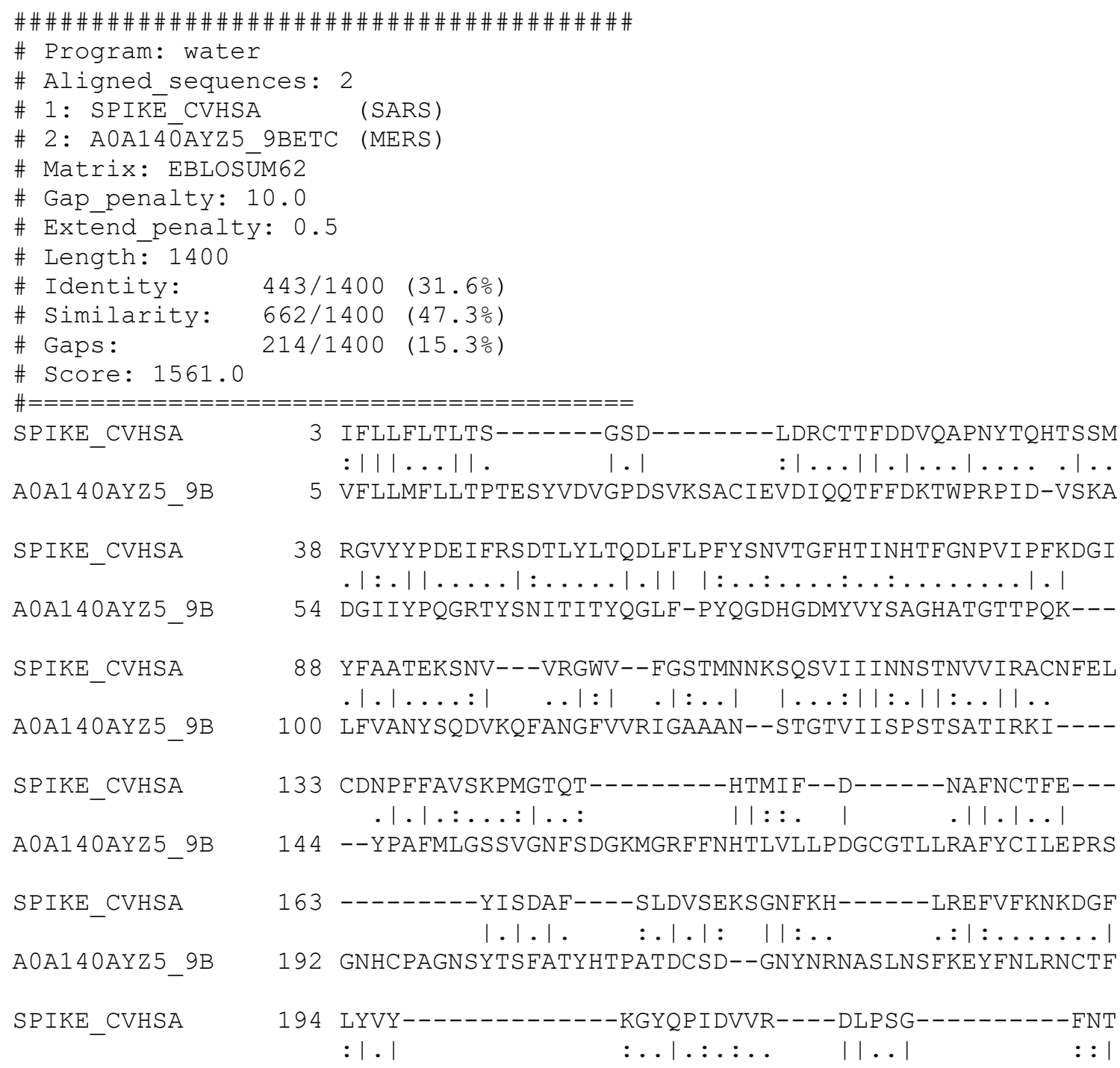


A0A140AYZ5_9B

SPIKE_CVHSA

A0A140AYZ5_9B

SPIKE_CVHSA

A0A140AYZ5_9B

SPIKE_CVHSA

A0A140AYZ5_9B

SPIKE CVHSA

A0A140AYZ5_9B

SPIKE_CVHSA

A0A140AYZ5 9B

SPIKE_CVHSA

A0A140AYZ5_9B

SPIKE_CVHSA

A0A140AYZ5_9B

SPIKE_CVHSA

A0A140AYZ5_9B

SPIKE_CVHSA

A0A140AYZ5_9B

SPIKE_CVHSA

A0A140AYZ5_9B

SPIKE_CVHSA

A0A140AYZ5_9B

SPIKE_CVHSA

A0A140AYZ5_9B

SPIKE_CVHSA

A0A140AYZ5_9B

SPIKE_CVHSA

A0A140AYZ5_9B

SPIKE_CVHSA

A0A140AYZ5_9B
240 MYTYNITEDEILEWFGITQTAQGVHLFSSRYVDLYGGNMFQFATLPVYDT

216 LKPIFKLPLGINITNFRAILTAFSPAQDIWGTSAAAYFVGYLKPTTFMLK $:|\ldots:| \ldots \mid$. :...... ||$::|\ldots|:||.|:|$.

290 IKYYSIIPHSIR---------SIQSDRKAW----AAFYVYKLQPLTFLLD

266 YDENGTITDAVDCSQNPLAELKCSVKSFEIDKGIYQTSNFRVVPSGDVVR $: \ldots:|.| \ldots|:||\ldots| .|::| .|| .:||:::$. $|:| \ldots|:| \ldots|||| \mid$. .

327 FSVDGYIRRAIDCGFNDLSQLHCSYESFDVESGVYSVSSFEAKPSGSVVE

316 FPNITNLCPFGEVFNATKFPSVYAWERKKISNCVADYSVLYNSTFFST-$\ldots \ldots|.| \ldots: . .|\cdot| \cdot|| .::|\ldots:||:|:: \ldots . .||$.

377 QAEGVE-CDFSPLLSGTP-PQVYNFKRLVFTNC--NYNLTKLLSLFSVND

364 FKCYGVSATKLNDLCFSNVYADSF----VVKGDDVRQIAPGQTGVIADYN $|.| \ldots:|\ldots: \ldots|:|:: \ldots| .|\quad .:| .|\quad:: \ldots| ..|:$. 423 FTCSQISPAAIASNCYSSLILDYFSYPLSMKSD----LSVSSAGPISQFN

410 YKLPDDFMGC-VLAWNTRNIDATSTGNYNYKYRYLRHGKLRPFERDISNV ||$\ldots \ldots|:||\ldots|: \quad:|\ldots \ldots|||:. \ldots|\ldots| \ldots: \mid$ 469 YKQSFSNPTCLILATVPHNL---TTITKPLKYSYINKCS-RLLSDDRTEV

459 PFSPDG---KPCTPPALNCYWPLNDY----------GFYTTTGIGYQPY $|\ldots . . \quad| .1 \ldots . \ldots|\ldots||\quad|: \ldots: \mid \ldots \ldots$ 515 PQLVNANQYSPCVSTVPSTVWEDGDYYRKQLSPLEGGGWLVASGSTVAMT

495 RVVVLSFELLNAPAT----VCGPKL---STDLIKNQ---CVNFNFNGLTG $\ldots: . . . \ldots \ldots|\quad||||| \quad: \ldots|.:| \quad|| .: \ldots|::|$ 565 EQLQMGFGITVQYGTDTNSVC-PKLEFANDTKIASQLGNCVEYSLYGVSG

535 TGVL---TPSSKRFQPF--QQFGRDVSDFTDSVRDPKTSEILDISPCSFG . $\mid$ | $|\ldots ..| .|\quad \ldots: \ldots| \ldots:$. . . . .......... 614 RGVFQNCTAVGVRQQRFVYDAYQNLVGYYSDD------GNYYCLRACVSV

580 GVSVITPGTNASSEVAVLYQDVNCTDVSTAIHADQLTPAWR-IYSTGNNV

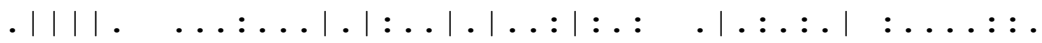
658 PVSVIY--DKETKTHATLFGSVACEHISSTM--SQYSRSTRSMLKRRDST

629 F---QTQAGCLIGAEHVDTSY---ECDIPIGAGICASYHTVSLLRSTSQK $: \quad|| \ldots||::|. \quad|::|. \quad:| .:|:| \ldots:|| \ldots|| ..|\ldots| .:$ 704 YGPLQTPVGCVLGL--VNSSLFVEDCKLPLGQSLCALPDTPSTLTPRSVR

673 SI--------VAYTMSLGADSSIAYSNNTIAIPTNFSISITTEVMPVSMA $|: \quad:|: \ldots: \ldots|\ldots: \ldots| \ldots::|||||| \ldots:|.| \ldots::$. 752 SVPGEMRLASIAFNHPIQVD-QLNSSYFKLSIPTNFSFGVTQEYIQTTIQ

715 KTSVDCNMYICGDSTECANLLLQYGSFCTQLNRALSGIAAEQDRNTREVF $|\ldots:||| \ldots|:| \ldots .|\ldots||.:|||.|:::|:|| .|\ldots||\ldots:.| .: \mid$ 801 KVTVDCKQYVCNGFQKCEQLLREYGQFCSKINQALHGANLRQDDSVRNLF

765 AQVKQMYKTPTLKYFGG-FNFSQILPDPLKP---TKRSFIEDLLFNKVTL $||.|\ldots:| \ldots: \ldots|||||\ldots: ..| \ldots: \ldots \quad: .|| \cdot||||||:|| \mid:$ 851 ASVKSSQSSPIIPGFGGDFNLTLLEPVSISTGSRSARSAIEDLLFDKVTI

811 ADAGFMKQYGECL--GDINARDLICAQKFNGLTVLPPLLTDDMIAAYTAA ||$.|:|: .|.:|:|\ldots:||||||||\ldots| \ldots|||||: \ldots:| .||||:$ : 901 ADPGYMQGYDDCMQQGPASARDLICAQYVAGYKVLPPLMDVNMEAAYTSS

859 LVSGTATAGWTFGAGAALQIPFAMQMAYRFNGIGVTQNVLYENQKQIANQ $|: \ldots| \ldots|||.| \ldots: \ldots|||| \ldots: .|| .||:|:|||.||||.||||:$. 951 LLGSIAGVGWTAGLSSFAAIPFAQS IFYRLNGVGITQQVLSENQKLIANK 


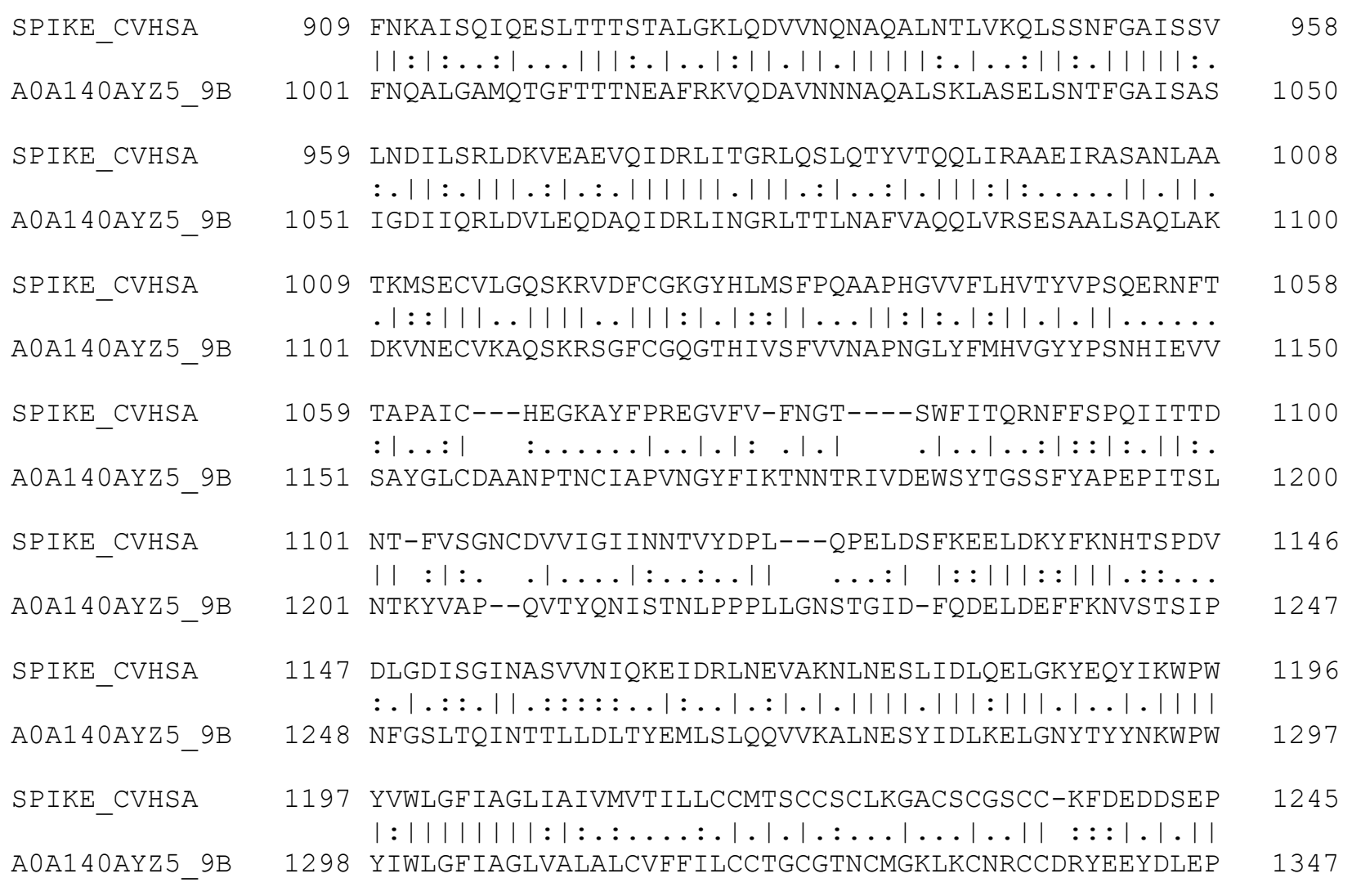

Fig. 3. Alignment result between MERS CoV with SARS CoV spike glycoproteins.

Table 1 represents the results of the alignment shown by the value of identity and similarity. The Identity is the percentage of identical matches between the two sequences over the reported aligned region (including any gaps in the length). The following are the results of alignment among the three viruses.

Table 1. Conclusions on the alignment results of the coronavirus spike glycoprotein.

\begin{tabular}{llll}
\hline No & Aligned Type & $\begin{array}{l}\text { Identity } \\
(\%)\end{array}$ & $\begin{array}{l}\text { Similarity } \\
(\%)\end{array}$ \\
\hline 1 & Covid-19 x SARS & 76.4 & 87.0 \\
2 & Covid-19 x MERS & 30.1 & 45.4 \\
3 & SARS x MERS & 31.6 & 47.3 \\
\hline
\end{tabular}

The similarity is the percentage of matches between the two sequences over the reported aligned region (including any gaps in the length) (Taupiqurrohman et al., 2016). In addition, Identity value indicates the identical equation of the compared amino acids, while the similarity value indicates the conformity on chemical properties (Hui et al., 2020). Table 1 also shows that Coronaviruses of SARS and COVID-19 have a high similarity with an identity value of $76.4 \%$ and $87 \%$. On the contrary, the comparison of MERS and COVID-19 is relatively not similar because the alignment results are below $70 \%$. The low result is also shown by the comparison between SARS with MERS having 31.6\% identity, and $47.3 \%$ similarity. This is consistent with the explanation of Andriani (2016) and Li et al. (2020), where it was stated that the coronaviruses of SARS and COVID-19 are very close based on evolution tree. According to Rice et al. (2000), phylogenetic results (evolutionary kinship) cannot be concluded because of the type of protein being compared. Therefore, this research has illustrated the great potential of spike glycoprotein to be the source of peptide vaccine candidates for the SARS and COVID-19 diseases. Below is the structure of the spike glycoprotein of SARS-CoV, SARSCoV-2, and MERS based on the database (pdb.org). 


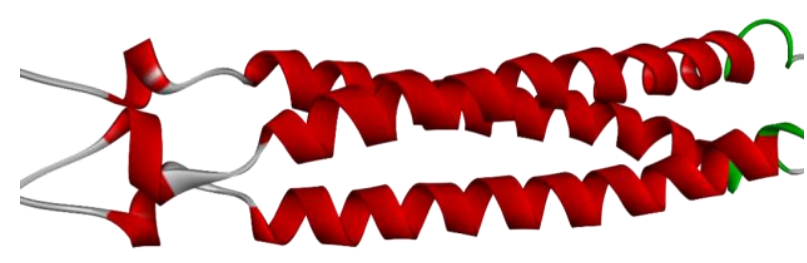

Fig. 4. Structure of SARS-CoV spike glycoproteins.

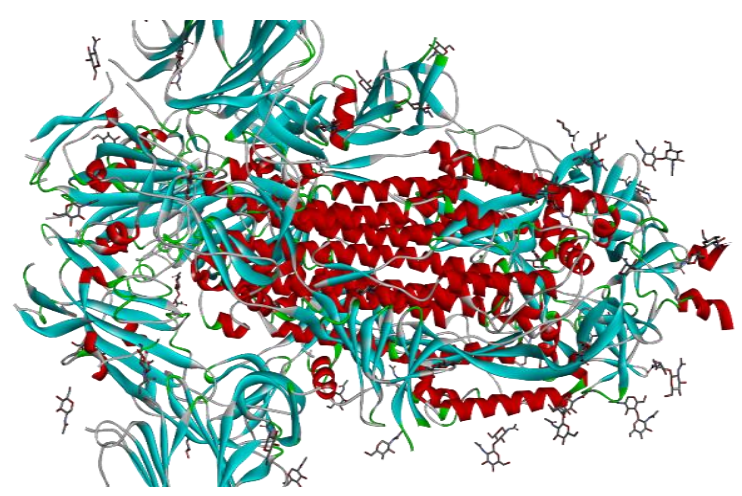

Fig. 5. Structure of SARS CoV-2 spike glycoproteins.

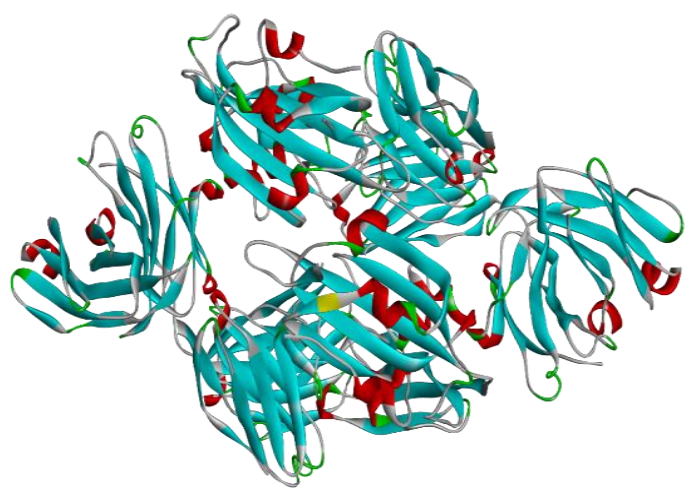

Fig. 6. Structure of SARS CoV spike glycoproteins

Work Principles of Universal Peptide Vaccine. The sequential analysis shows that spike glycoprotein can only be used as the source of peptide vaccine candidates for SARS and COVID-19. This should be properly conducted since the working principle of peptide vaccine is based on the immune system. The two common parts when a virus infects are the outside (specific body tissue) and the inside of an infected cell (body cell). When a part of the tissue is infected, the immune cells in the region begin to respond (Mothes et al., 2010; Mallapaty, 2020). This is evident in macrophages, which is one type of immune cell that is responsible for initiating the formation of antibodies through the activation of helper $T$ cells. To activate this cells, macrophages will phagocytize the incoming antigen protein. Furthermore, the results of phagocytosis (small peptides) are raised to the surface of the body by major histocompatibility (MHC) class II protein to be recognized by helper $\mathrm{T}$ cell receptors (Li et al., 2020). Andriani (2016) stated the predicted part and made into a peptide vaccine.

During an internal cellular infection, the cell responds through a series of reactions (Fig. 4). An important part of this response in relation to the peptide vaccine is that the cell will attempt to bring the virus part to the surface. This is conducted by the MHC class I and recognized by cytotoxic $\mathrm{T}$ cells, which functions to reduce infection (Li et al., 2020). The part of the virus raised by MHC I and II is another peptide vaccine candidate that is predicted by using the spike glycoprotein (marked in the box in the picture). This protein is a potential candidate for peptide vaccine since it is found on the outer part of the virus spike glycoprotein is also in the outer part of the virus, thus it is a potential candidate for peptide vaccine. Initially, it is recognized or attached to the cell surface, and the location is given below.

Every disease has a cure. If the right medicine is found for a disease, the disease will be cured with the permission of Allah Azza wa Jalla (Sahih Muslim No. 4084). Based on this hadith, we can learn that there is no disease on this earth that was created by Allah swt. without a cure. As at present, many kinds of research have been carried out by scientists to find the most appropriate vaccine candidates for use in the prevention of infectious diseases caused by the coronavirus. The success of finding a vaccine candidate with the highest level of effectiveness is also inseparable from the power of Allah Almighty, as His word in QS. AshShu'ara verse 80 (Kementerian Agama RI, 2019). This verse explains that it is Allah swt. who heals a man when he is sick. Allah has the power to heal any disease that a person has. But man, through the use of the mind by studying science, must also find out how to obtain this healing. Through science, humans can find out 
the types of amino acids from the glycoprotein spike of various types of coronaviruses that are most appropriate to be used in the production of universal peptide vaccines for various types of infectious diseases caused by various types of coronaviruses. The lesson that can be taken from this verse is that diseases experienced by humans are the result of human actions themselves, including infection with diseases caused by the coronavirus, one of which is the lack of a clean lifestyle. Through the efforts made by humans and by the will of Allah swt. diseases suffered by humans can be cured. Diseases that occur in humans can also be a reminder to always be grateful for the various blessings from Allah swt. One of which is the favor of healing from an illness.

\section{CONCLUSION}

SARS CoV-2 (COVID-19) and SARS are very similar with $87 \%$ similarity and $76.4 \%$ identity values. In contrast, covid-19 with MERS and SARS with MERS are very different because of their reduced similarity and identity values below $70 \%$. Therefore, the spike glycoprotein can only be used as the peptide vaccine candidate for COVID-19 and SARS.

\section{REFERENCES}

Abroug F, Slim A, Ouanes-Besbes L, Kacem MAH, Dachraoui F, Ouanes I, Lu X, Tao Y, Paden C, Caidi H, Miao C, Al-Hajri MM, Zorraga M, Ghaouar W, BenSalah A, Gerber SI. 2014. Family cluster of Middle East respiratory syndrome coronavirus infections, Tunisia, 2013. Emerging Infectious Diseases. vol 20(9): 1527-1530. doi: https://dx.doi.org/10.3201\%2Feid2009.140378.

Alouane T, Laamarti M, Essabbar A, Hakmi M, Bouricha EM, Chemao-Elfihri MW, Kartti S, Boumajdi N, Bendani H, Laamarti R, Ghrifi F, Allam L, Aanniz T, Ouadghiri M, Hafidi NE, Jaoudi RE, Benrahma H, Attar JE, Mentag R, Sbabou L, Nejjari C, Amzazi S, Belyamani L, Ibrahimi A. 2020. Genomic diversity and hotspot mutations in 30,983 SARS-CoV-2 genomes: moving toward a universal vaccine for the "confined virus"?. Pathogens. vol 9(10): 1-19. doi: https://doi.org/10.3390/pathogens9100829.

Andriani T. 2016. Application of Upgma method to identify kinship types of viruses and spread of Ebola epidemic through the formation of phylogenetic trees. [Thesis]. Surabaya: Magister Program in Mathematics Faculty of Mathematics and Natural Sciences Institute of Technology ten November.
Aprilyanto V, Sembiring L. 2017. Bionformatics. Yogyakarta: Innosains.

Cunha CB, Opal SM. 2014. Middle East respiratory syndrome (MERS) a new zoonotic viral pneumonia. Virulence. vol 5(6): 650-654. doi: https://doi.org/10.4161/viru.32077.

da Costa VG, Moreli ML, Saivish MV. 2020. The emergence of SARS, MERS and novel SARS-2 coronaviruses in the 21st century. Archives of Virology. vol 165(7): 1517-1526. doi: https://doi.org/10.1007/s00705-020-04628-0.

Hui DS, Azhar EI, Madani TA, Ntoumi F, Kock. 2020. The continuing 2019-nCoV Epidemic Threat of Novel Coronaviruses to Global Health — The Latest 2019 Novel Coronavirus Outbreak in Wuhan, China. International Journal of Infectious Diseases. vol 91: 264-266. doi: https://doi.org/10.1016/j.ijid.2020.01.009

ICTV. 2020. Naming the 2019 Coronavirus. London: International Committee on Taxonomy of Viruses. https://talk.ictvonline.org/.

Jeong SY, Sung SI, Sung JH, Ahn SY, Kang ES, Chang YS, Park WS, Kim JH. 2017. MERS-CoV infection in a pregnant woman in Korea. Journal of Korean Medical Science. vol 32(10): 1717-1720. doi: https://doi.org/10.3346/jkms.2017.32.10.1717.

Kementerian Agama RI. 2019. Terjemahan Al Qur'an Surat Ash-Shu'ara ayat 80. https://quran.kemenag.go.id/.

Khalaj-Hedayati A. 2020. Protective immunity against SARS subunit vaccine candidates based on spike protein: lessons for coronavirus vaccine development. Journal of Immunology Research. vol 2020: 1-11. doi: https://doi.org/10.1155/2020/7201752.

Li B, Si H-R, Zhu Y, Yang X-L, Anderson DE, Shi Z-L, Wang L-F, Zhou P. 2020. Discovery of bat coronaviruses through surveillance and probe capture-based next-generation sequencing. Msphere. vol 5(1): 1-11. doi: https://doi.org/10.1128/mSphere.00807-19.

Li G, Fan Y, Lai Y, Han, T, Wang HD. 2020. Coronavirus infections and immune responses. Journal of Medical Virology. vol 92(4): 424-432. doi: https://doi.org/10.1002/jmv.25685.

Liu D X, Fung, T S, Kian K, Chong L, Shukla A, Hilgenfeld, R. 2014. Accessory proteins of SARS$\mathrm{CoV}$ and other coronaviruses. Antiviral Research. vol 109: 97-109. doi: https://doi.org/10.1016/j.antiviral.2014.06.013.

Mailles A, Blanckaert K, Chaud P, van der Werf S, Lina B, Caro V, Campese C, Guéry B, Prouvost H, Lemaire X, Paty M C, Haeghebaert S, Antoine D, Ettahar N, Noel H, Behillil S, Hendricx S, Manuguerra J C, Enouf V, La Ruche G, Semaille C, Coignard B, Lévy-Bruhl D, Weber F, Saura C, Che D. 2013. The investigation team collective. first cases of middle east respiratory syndrome coronavirus (MERS-CoV) infections in France, investigations and implications for the prevention 
of human-to-human transmission, France, May 2013. Eurosurveillance. vol 18(24): 1-5. doi: https://doi.org/10.2807/ese.18.24.20502-en.

Mallapaty S. 2020. Mini organs reveal how the coronavirus ravages the body. Nature. vol 583(7814): 15-16. doi: https://doi.org/10.1038/d41586-020-01864-x.

Mothes W, Sherer NM, Jin J, Zhong P. 2010. Virus cellto-cell transmission. Journal of Virology. vol 84(17): 8360-8368. doi: https://doi.org/10.1128/JVI.00443-10.

Peiris JSM, Yuen KY, Osterhaus ADME, Stöhr K. 2003. The Severe Acute Respiratory Syndrome. The New England Journal of Medicine. vol 349(25): 24312441. doi: https://doi.org/10.1056/NEJMra032498.

Puzelli S, Azzi A, Santini MG, Di Martino A, Facchini M, Castrucci MR, Meola M, Arvia R, Corcioli F, Pierucci F, Baretti S, Bartoloni A, Bartolozzi D, de Martino M, Galli L, Pompa MG, Rezza G, Balocchini E, Donatelli I. 2013. Investigation of an imported case of middle east respiratory syndrome coronavirus (MERS-CoV) infection in Florence, Italy, May to June 2013. Eurosurveillance. vol 18(34): 1-4. doi: https://doi.org/10.2807/15607917.ES2013.18.34.20564.

Racelis S, de los Reyes VC, Sucaldito MN, Deveraturda I, Roca JB, Tayaga E. 2015. Contact tracing the first Middle East respiratory syndrome case in the Philippines. Western Pacific Surveillance and Response Journal. vol 6(3): 3-7. doi: https://dx.doi.org/10.5365\%2FWPSAR.2015.6.2.0 12.

Rampengan NH. 2016. Middle East Respiratory Syndrome Coronavirus. Jurnal Biomedik. vol 8(1): $17-26$. doi: https://doi.org/10.1177/2165079915607497.

Rashid H, Azeem MI, Heron L, Haworth E, Booy R, Memish ZA. 2013. Has Hajj-associated MERS$\mathrm{CoV}$ transmission occurred? The case for effective post-Hajj surveillance for infection. Clinical Microbiology Infection. vol 20(4): 271-276. doi: https://doi.org/10.1111/1469-0691.12492.

Rice P. Longden I, Bleasby A. 2000. EMBOSS: The European Molecular Biology Open Software Suite. Trends in Genetics. vol 16(6): 276-277.

Sahih Muslim No. 4084/Sahih Muslim 2204; In-book reference: Book 39, Hadith 95; USC-MSA reference: Book 26, Hadith 5466.

Schoeman D, Fielding BC. 2019. Coronavirus envelope protein: current knowledge. Virology Journal. vol 16(1): 1-22. doi: https://doi.org/10.1186/s12985019-1182-0.

Shapiro M, London B, Nigri D, Shoss A, Zilber E, Fogel I. 2016. Middle East respiratory syndrome coronavirus: review of the current situation in the world. Disaster and Military Medicine. vol 2(1): 15. doi: https://doi.org/10.1186/s40696-016-0019-2.

Shereen MA, Khan S, Kazmi A, Bashir N, Siddique R. 2020. COVID-19 Infection: Origin, transmission, and characteristics of human coronaviruses. Journal of Advanced Research. vol 24: 91-98. doi: https://doi.org/10.1016/j.jare.2020.03.005.

Slamet, Bratasena, A., Sitorus, M., Rizkiyat, N., Samoedro, E., Wignjadiputro. 2013. General guidelines on readiness to face middle east respiratory syndrome-corona virus (MERS-CoV). Jakarta: Directorate General of Environmental Control and Investigation of Ministry of Health Republic of Indonesia.

Subroto T, Hardianto A, Abdul Alim Kahari, Tika Pradnjaparamita. 2013. Protective group peptide synthesis as a component precursor to Universal Influenza vaccines. Bandung: PTNBR - BATAN.

Taupiqurrohman O, Yusuf M, Nuswantara S, Subroto T. 2016. Potensi Gen Oncoprotein Human Papillomavirus Tipe 16 Sebagai Kandidat Vaksin Kanker Serviks. Majalah Kedokteran Bandung. vol 48(2): 84-91.

doi: https://doi.org/10.15395/mkb.v48n2.761

Thomas HL, Zhao H, Green HK, Boddington NL, Carvalho CF, Osman HK, Sadler C, Zambon M, Bermingham A, Pebody RG. 2014. Enhanced MERS coronavirus surveillance of travelers from the Middle East to England. Emerging Infectious Diseases. vol 20(9): 1562-1564. doi: https://dx.doi.org/10.3201\%2Feid2009.140817.

Wang N, Shi X, Jiang L, Zhang S, Wang D, Tong P. 2013. Structure of MERS-CoV Spike ReceptorBinding Domain Complexed with Human Receptor DPP4. Cell Research. vol 23(8): 986.

WHO. 2016. Middle East Respiratory Coronavirus (MERS-CoV). Geneva: World Organization Health. http://www.who.int/emergencies/merscov/en/.

Wu F. Zhao S, Yu B. 2020. A new coronavirus associated with human respiratory disease in China. Nature. vol 579: 265-269. doi: https://doi.org/10.1038/s41586-020-2008-3.

Zhong N, Zheng B, Li Y, Poon L, Xie Z, Chan K. 2003. Epidemiology and cause of severe acute respiratory syndrome (SARS) in Guangdong, People's Republic of China, in February. The Lancet: vol 362(9393): 1353-1358.

Zumla A, Hui DS, Perlman S. 2015. Middle East respiratory syndrome. The Lancet. vol 386(9997: 995-1007. doi: 10.1016/S0140-6736(15)60454-8. 